\title{
Test of the maximum penetration depth of the Roteg GPR above the Hranice Abyss and in the Moravian Karst
}

\author{
Test maximální hloubky penetrace georadaru Roteg nad Hranickou propastí a \\ v Moravském krasu
}

\author{
Pavel Kalenda' $\square$, Rudolf Tengler ${ }^{2}$, Milan Geršl ${ }^{3}$ \\ ${ }^{1}$ CoalExp, Pražmo 129, 73904 Pražmo, Czech Republic \\ ${ }^{2}$ Ing. Rudolf Tengler - RTG, Českobratrská 357, 27601 Mělník, Czech Republic \\ ${ }^{3}$ Mendel university in Brno, Zemědělská 1, 61300 Brno, Czech Republic
}

Key words:

Ground Penetrating Radar, penetration depth, karst, Hranice Abyss, limestones

凸 pkalenda@volny.cz

Editor:

Marek Slobodník

\begin{abstract}
A new kind of Ground Penetrating Radar (GPR), "Roteg", was tested at generally known speleological sites in the Czech Republic. The first examined site - the Hranice Abyss located near the town Hranice - is the deepest underwater cave in the world.

This GPR is characterised by much higher pulse power, antennas with rather high voltage (5-15 kV), and, in particular, the special design of the pulse generator.

The radar survey near the Hranice Abyss has shown that it is possible to detect reflections of electromagnetic pulses coming from the speleogenic structures of the abyss itself and from lithological boundaries occurring below the water table - something which was not anticipated and was verified for the first time ever. Plausibly detectable reflections were detected from the depths of $580 \mathrm{~m}$ below the surface - which is approximately $515 \mathrm{~m}$ below the water level - using the longest available 6-metre antennas tuned to the frequency of $25 \mathrm{MHz}$.

The second site tested was the quarry of Malá Dohoda near the municipality of Holstejn, the Moravian Karst, the Czech Republic. The GPR used was the same as above except the power output to the transmitting antenna which produced pulses of $20 \mathrm{kV}$. The radarogram showed cavities located at the depth of up to $300 \mathrm{~m}$, the layers on the boundary between Lažánky and Vilémovice members oflimestone at the depth of $400 \mathrm{~m}$, basement sandstones and conglomerates at the depth of 600-700 $\mathrm{m}$, and granite rocks below this level.

Both of the tests mentioned above confirmed the extraordinary big penetration depth of the GPR signal which exceeded $500 \mathrm{~m}$ when using the maximum power on transmitting antennas.
\end{abstract}

\section{Abstrakt}

Na známých speleologických lokalitách $v$ České republice byl testován nový druh georadaru (GPR), „Roteg“. První zkoumaná lokalita - Hranická propast u Hranic - je nejhlubší podvodní jeskyní na světě.

Tento georadar se vyznačuje mnohem vyšším pulzním výkonem než běžné georadary, velmi vysokým napětím (5-15 kV) na vysílací anténě a zejména speciální konstrukcígenerátoru impulzu.

Radarový průzkum pobliž Hranické propasti ukázal, že je možné detekovat odrazy elektromagnetických pulzů prícházejících od jeskynních struktur samotné propasti a od litologických hranic vyskytujících se pod hladinou podzemní vody, tedy něco, co se vůbec nepredpokládalo a bylo takto poprvé in-situ ověreno. Věrohodné odrazy byly detekovány ažz hloubek 580 m pod povrchem, cožje príibližně 515 m pod hladinou vody, a to za pomocí nejdelšich dostupných 6 metrových antén, naladěných na frekvenci $25 \mathrm{MHz}$.

Druhým testovaným místem byl lom Malá Dohoda u obce Holštejn v Moravském krase. Použitý georadar byl stejný jako v předchozím př́padě, s výjimkou výstupu generátoru pulzủ, který generoval impulsy o napětí až $20 \mathrm{kV}$ na vysílací anténě. Na radarogramu byly patrné odrazy signálu od dutin ve vápencích v hloubkách až $300 \mathrm{~m}$, od litologických rozhraní mezi Lažáneckými a Vilémovickými vápenci v hloubce 400 m, bazálními pískovci 
a slepenci v hloubce 600-700 m a žulami (Brněnská vyvřelina) pod touto úrovni.

Oba výše uvedené testy potvrdily mimořádně velký hloubkový dosah georadaru "Roteg“, který byl při použití maximálního výkonu vysílacích antén $v$ krasových oblastech větší než $500 \mathrm{~m}$.

\section{Introduction}

The Ground Penetrating Radar (GPR) measurement is one of most effective geophysical measurements in the field. GPR is based on the transmission of high frequency pulses by one antenna and on receiving the reflections of those pulses by another antenna. A delay $\mathbf{t}$ of the reflections is proportional to the depth $\mathbf{d}$ of the interface of materials with different permittivities $\left(\varepsilon_{1}, \varepsilon_{2}\right)$ that reflects the pulses and indirectly proportional to the velocity $\mathbf{v}$ following the relationship of $t=2 d / v$. The velocity $\mathbf{v}$ depends on the permittivity $\varepsilon_{1}$ of the material following the relationship of $\mathrm{v}=\mathrm{c} / \sqrt{\varepsilon_{\mathrm{r}}}$, where $\mathrm{c}$ is speed of light and $\varepsilon_{\mathrm{r}}$ is relative permittivity. Limestone has relative permittivity of 2.0-2.5 and typical velocity of $12-14 \mathrm{~cm} / \mathrm{ns}$. Fresh water has relative permittivity of 9-10 and typical velocity of $3 \mathrm{~cm} / \mathrm{ns}$ (Annan 2005). Therefore, wet limestone with the porosity of $5 \%$ has the velocity of $10-12$ $\mathrm{cm} / \mathrm{ns}$. The amplitude of reflections is proportional to the ratio of permittivities $\varepsilon_{1}$ and $\varepsilon_{2}$ of these materials and decreases exponentially with depth, depending on the electric conductivity of the material (van der Kruk et al. 1999; Gosar 2012).

For commonly used GPR and typical environments in Central Europe with the resistivity of hundreds $\Omega \mathrm{m}$, the penetration depth can be a few metres for GPRs with the power output of 300-1500 W and the centre frequency of 500-1 $000 \mathrm{MHz}$ [for example, IRIS GPRs or the ProEx GPR unit (MALA Geoscience, Sweden; Łyskowski et al. 2014)] up to several ten metres for several $\mathrm{kW}$ power

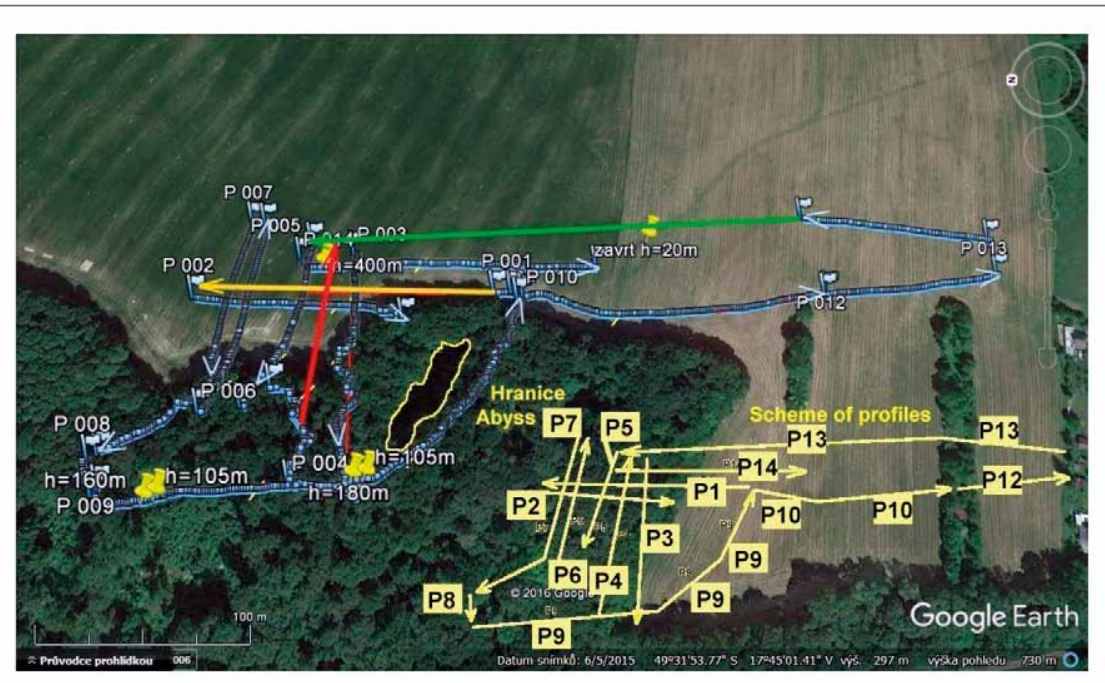

Fig. 1: Profiles P1-P14 around the Hranice Abyss (blue GPS dots), scheme of profiles are in light yellow. The profile name is indicated at the beginning of the profiles. Yellow arrow: profile P1, red arrow: profile P4, green arrow: the second part of profile P13 (GPS was out of operation after the interruption of the measurement). (Credit: Google Earth) output and 25-50 MHz centre frequency (Chamberlain et al. 2000). Smith and Jol (1995) experimentally estimated that the penetration depth for a $25 \mathrm{MHz}$ antenna and the Quaternary sedimentary environment (above the surface of mineralised water) is between 52 and 57 metres. For a $100 \mathrm{MHz}$ antenna the penetration depth reduced to $37 \mathrm{~m}$. The results of experimental measurements above the cave of Divaška Jama (Gosar 2012) and above the S-19 Cave on the Kanin massif (Gosar, Čeru 2016) correspond to such estimations.

In 2013, a new type of GPR (Roteg) was developed, one with an extremely high pulse power output of several MW on antenna (Tengler 2013). Two localities were found to test the maximal penetration depth - the Hranice Abyss (HA) (Fig. 1), which is the world's deepest flooded cave with a depth of more than $404 \mathrm{~m}$, according to figures recorded so far (Guba 2016; Musil 2017). The next test of the penetration depth of the Roteg GPR was carried out in the quarry of Malá Dohoda, Holštejn near Blansko, and the results were compared with the geological crosssection (Baldík et al. 2017) that was traced in the distance of approx. $1 \mathrm{~km}$ from the quarry.

Three Key Points: 1) New kind of Ground Penetrating Radar, 2) Field test of the penetration depth at the Hranice Abyss and in the Moravian Karst, 3) Maximum penetration depth to be more than $500 \mathrm{~m}$ in limestones.

\section{Methodology and methods}

Compared with the existing GPRs, the new GPR termed Roteg is characterized by a much higher pulse power, higher voltage of antennas $(5-20 \mathrm{kV})$, and, in particular, the special design of the pulse generator, which bypasses the frequently used semiconductor components of MOS and LDMOS, and makes use of a spark gap. This allows increasing the power output on antenna up to several MW, which is at least 2 orders more than for conventional GPRs. The increasing power output of 2 orders implies increasing maximal penetration depth of at least one order in the same conditions. The spark gap (discharger) produces Dirac pulses of lengths of up to $3 \mathrm{~ns}$ by directly discharging capacitors (RTG-Tengler 2013). The predominant frequencies are selected from the continuous spectrum by a special antenna, which is tuned to them. Each antenna has a flat spectrum, i.e., is sensitive to all of the frequencies within the continuous spectrum, but the corner frequency of the spectrum depends on the length of the antenna. The 6-metre antenna is tuned to the predominant frequency of $25 \mathrm{MHz}$, the 3-metre antenna to $50 \mathrm{MHz}$, and 1-metre antenna to $150 \mathrm{MHz}$. 


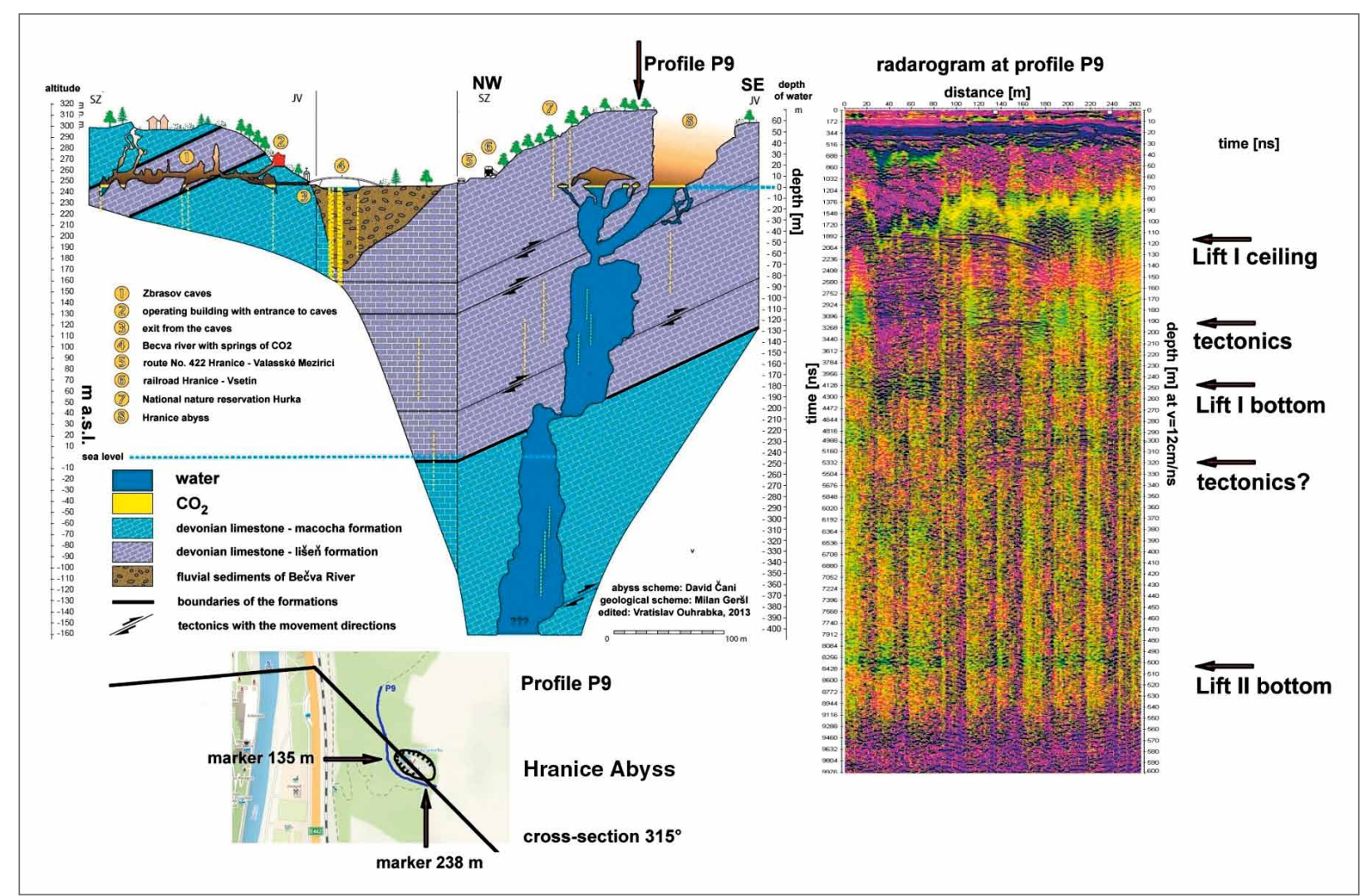

Fig. 2: The geological cross-section of the Hranice Abyss and the radarogram of profile P9. The red arrow marks the intersection of profile P9 and the cross-section of the Hranice Abyss in the position of $135 \mathrm{~m}$ on profile P9.

In both cases, i.e., the Hranice Abyss and the quarry of Malá Dohoda, the longest antenna $(6 \mathrm{~m})$ was used. The voltage on transmitting antenna was $15 \mathrm{kV}$ in the case of the abyss and $20 \mathrm{kV}$ in the case of the quarry. Approximately 10 pulses (frequency of pulse generation is $120 \mathrm{~Hz}$ ) were stacked, at the speed of approx. $3 \mathrm{~km} / \mathrm{h}$, into one sum, which represented one step of the measurement, i.e. $0.1 \mathrm{~m}$. The accuracy of positioning this measurement point by means of online GPS was approx. $1 \mathrm{~m}$. The sampling frequency was $3.6 \mathrm{GHz}(0.277 \mathrm{~ns}$ per sample). The total length of records was 38572 samples in the case of the Hranice Abyss (10 $684 \mathrm{~ns}$ ) and 57253 samples in the case of the quarry of Malá Dohoda (15 890 ns).

The REFLEXW program (Sandmeier Software, Karlsruhe, Germany) was used for the data analysis and interpretation. The signal was amplified with depth, both $\mathrm{x}$ and $\mathrm{y}$ axes were averaged at 20 samples (elimination of VF noise), and frequencies below $0.6 \mathrm{MHz}$ and above $12 \mathrm{MHz}$ were reduced (filtered).

We were looking for hyperbolas or lines of reflections that can correspond to linear (2-D) or isometric (3-D) inhomogeneity with high permittivity contrast or contrast between various layers or blocks crossed by faults.

\section{Geology}

The Hranice Abyss is the deepest speleological structure in the Hranice Karst. In 2016, it was identified to be the world's deepest flooded cave (Šráček et al. 2019; Kamenský 2016; Musil 2017). The abyss is filled with mineral water with a high level of carbon dioxide (Šráček et al. 2019).

The Hranice Abyss is a "light hole" cave with the depth of $70 \mathrm{~m}$ down to the water level. The abyss evolved on the tectonics with prevailing direction WNW-ESE (Fig. 2). One of these faults creates one of the walls of the Hranice Abyss as well as Lifts I and II to the north-west from the light hole (Figs. 1 and 2).

Under the water surface, the abyss changes into a tilting wide corridor leading to the depth of $50 \mathrm{~m}$. This space is called Zubatice, which suggests the deeply corroded ceiling of this area. From here, the abyss continues as a nearly vertical shaft that widens to reach a diameter of about $30 \mathrm{~m}$ - Lift I (Vysoká 2017) - see Fig. 3.

A relatively small sub vertical corridor opens into the ceiling of Lift I, leading to the water surface where it opens into an area called Rotunda. The bottom of Lift I at the depth of $180 \mathrm{~m}$ ( $250 \mathrm{~m}$ below the surface) forms a significant tilting area with a shaft, partly blocked by tree trunks. From here, K. Starnawski reached another vertical shaft in 2012 - Lift II (Starnawski 2012). In 2014, K. Starnawski dropped a probe from the ceiling of Lift II to the depth of $384 \mathrm{~m}$; in 2016 , a groundwater robot manufactured by GRALmarine penetrated to the depth of $404 \mathrm{~m}$ without reaching the bottom (Kamenský 2016). At this depth, Lift II transforms into a wide corridor tilting towards N (NW-NE) - see Fig. 3.

Similarly to the Hranice Karst, the Moravian Karst is developed in the Devonian and Lower Carboniferous carbonates, part of the Macocha and Líšen formations 


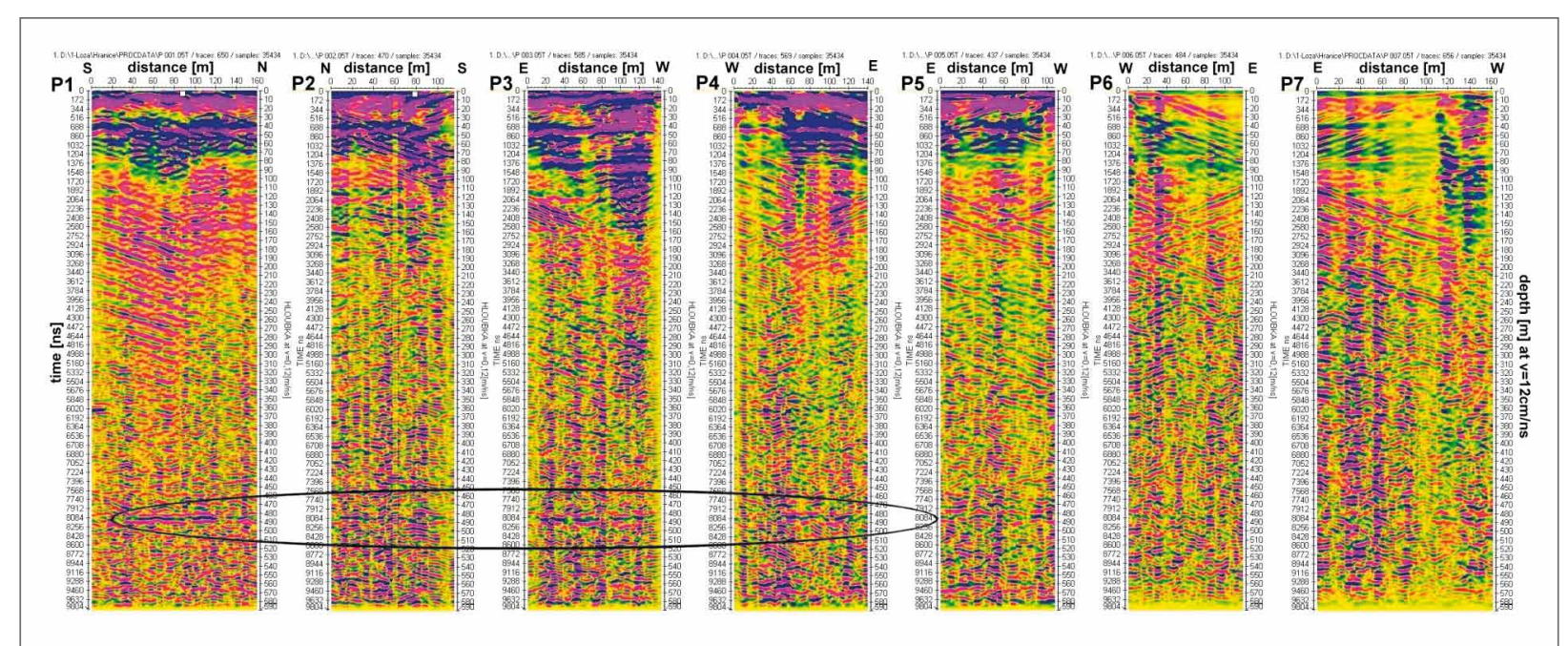

Fig. 3: Radarograms on profiles P1-P7. Ellipse: interpreted reflection boundary at a depth of $485 \mathrm{~m}(\mathrm{v}=12 \mathrm{~cm} / \mathrm{ns})$.

(upper Eifelian up to lower Visean). The basement of the Macocha formation is formed by Lower Devonian basal clastics represented by sandstones, conglomerates, arcoses and greywackes - the latter lay discordantly onto the Brno granite massif (Slezák 1955-1956; Slezák and Štelcl 1963; Hašek and Štelcl 1973).

Limestone in the roof gradually transforms into the Ostrov and Březina shales, Lower Carboniferous greywacke, and the shales of the Rozstání formation (Dvořák et al. 1993).

\section{Results of measurements above the Hranice Abyss}

The aim of the work was to detect reflections, both above (approx. $245 \mathrm{~m}$ a. s. 1.) and under the level of groundwater. Altogether, we measured 13 profiles in the surroundings of the Hranice Abyss (Fig.1). Profiles P1 to P8 and P14 (Figs. 3 and 4) allowed measuring the area north and east of the Hranice Abyss where the VLF measurement revealed a few tectonic lines of E-W to NW-SE directions (Geršl et al. 2007; Kalenda et al. 2007).

Georadar measurements at the Hranice Abyss were carried out on 4 November 2016, when the temperature on the surface dropped below zero. The typical speed of $12 \mathrm{~cm} / \mathrm{ns}$ for limestones was determined from the diffraction hyperbolas which were detected on Profile P9 (Fig. 2).

We can clearly see in profiles $\mathrm{P} 1-\mathrm{P} 4$ a reflection boundary at the depths of around 480$485 \mathrm{~m}$ (Fig. 3). In profile P5, this reflection is detectable only and, in the very north profiles of P6 and P7, it is completely missing. This reflection could represent a sub-horizontal corrosive plane formed near the groundwater surface in the past, or it could be a reflection from a structure in the abyss, i.e., the bottom, the ceiling, or a sub-horizontal / little-tilted interlayer plane. We must exclude a possible reflective structure on the surface at the same (time) distance of $175 \mathrm{~m}$ from profiles $\mathrm{P} 1-\mathrm{P} 4$ (for the speed of $33 \mathrm{~cm} / \mathrm{ns}$ ) because any such structure existing on the surface would create a diffraction hyperbola, which is not the case here.

The most illustrative was the radarogram of profile P9 that ran in the north-south direction above Rotunda, Lift I, and Lift II (Fig. 2), and then around the southern wall of the abyss to SE. We wanted to confirm or disprove the possibility of detection of reflections from the ceilings of Lift I or Lift II below the level of mineralised groundwater. In the radarogram of profile P9 (Fig. 2), we can clearly see a number of reflections from inhomogeneities from a limited space that form typical hyperbolas defined by the wave reflection into other directions than

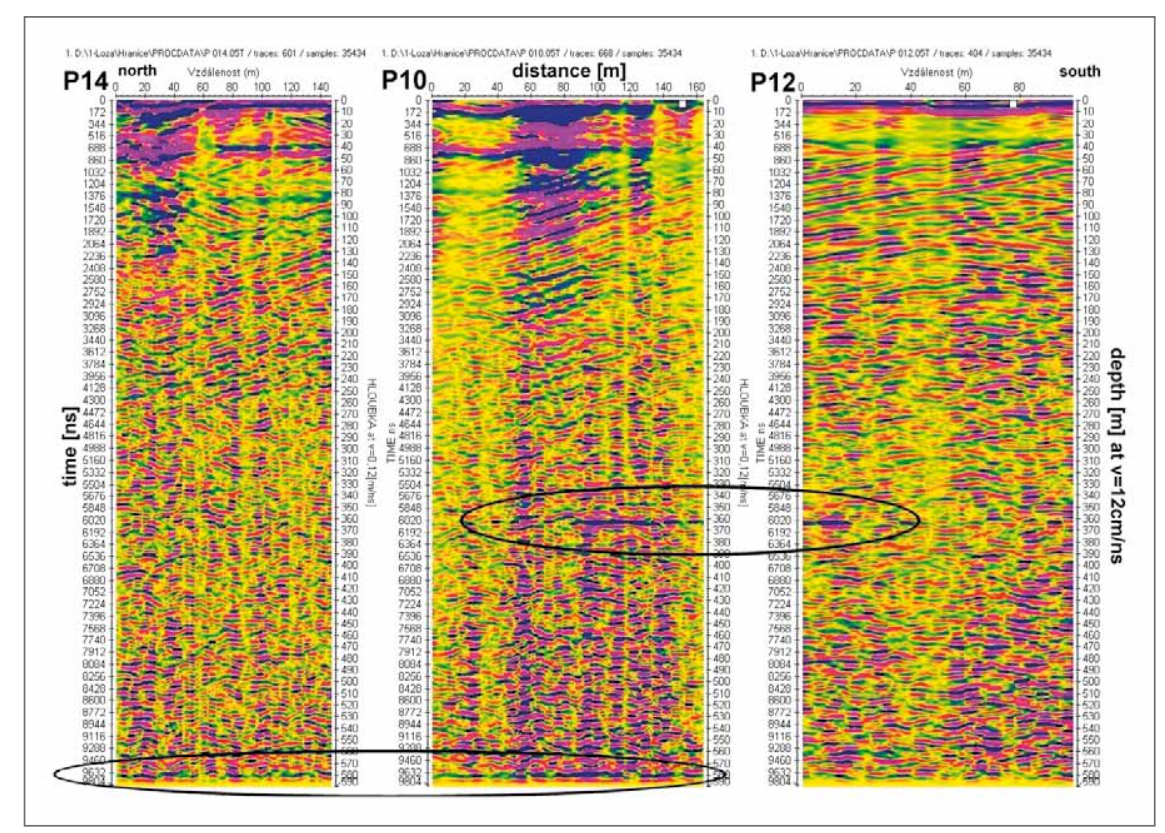

Fig. 4: Radarograms on profiles P14 (north) - P12 (south). Ellipses: interpreted reflection boundaries at depths of $360 \mathrm{~m}$ and $580 \mathrm{~m}(\mathrm{v}=12 \mathrm{~cm} / \mathrm{ns})$. 


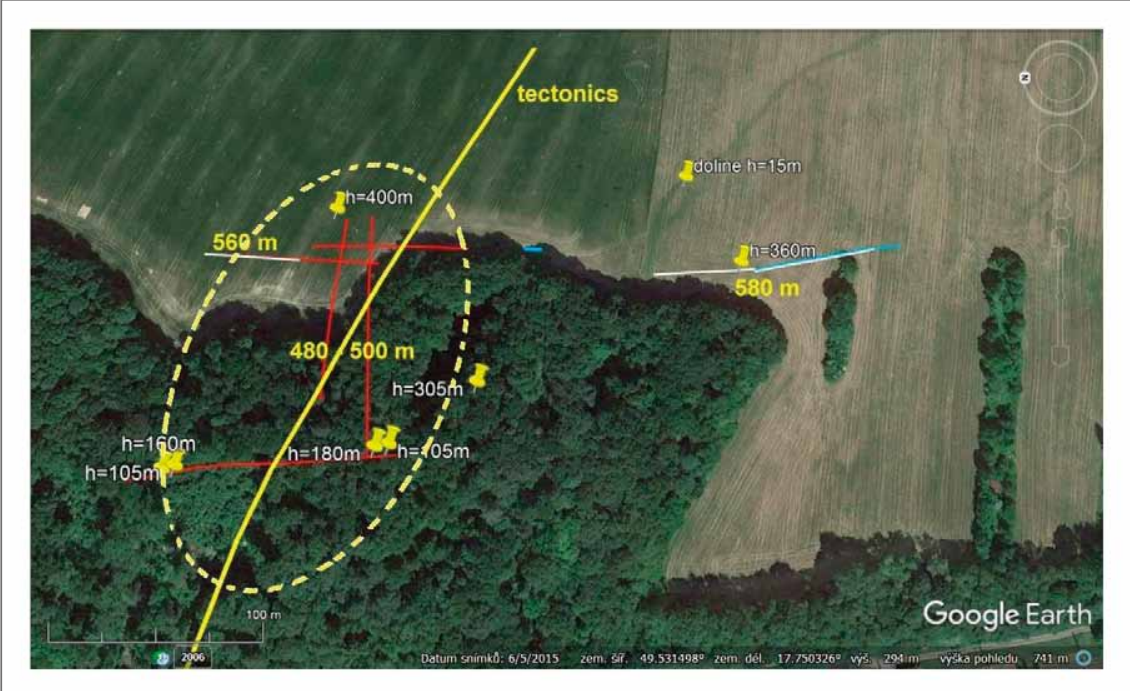

Fig. 5: The map with radarogram interpretations. Thumb-tacks mark the positions of significant $2 \mathrm{D}$ or $3 \mathrm{D}$ structures (probably caves) with the depth below the surface. Light blue lines along profiles: a sub-horizontal boundary detected at the depth of $360 \mathrm{~m}$ below the surface. Red lines along profiles: a sub-horizontal boundary detected at the depth of $485 \mathrm{~m}$ below the surface. White lines along profiles: a sub-horizontal boundary detected at the depth of $580 \mathrm{~m}$ below the surface. Yellow ellipse: an area of deep horizons at the depths of 100-560 m below the surface. Yellow lines: tectonics according to VLF measurements (Kalenda et al. 2007; Geršl et al. 2007).

those perpendicular to the boundary. The most prominent hyperbola has its peak at the depth of $105 \mathrm{~m}$ in the position on profile P9 of $115 \mathrm{~m}$. It can correspond to the tectonic line on which Zubatice or the ceiling of Lift I were developed. The area of another boundary is much larger, which is evident in the long linear reflection at the depths of $140-145 \mathrm{~m}$ and positions of $30-70 \mathrm{~m}$. Another prominent hyperbola has its peak in the position of $20 \mathrm{~m}$ and at the depth of $160 \mathrm{~m}$; it continues with a long linear reflection as far as another hyperbola with its peak in the position of $150 \mathrm{~m}$ and at the depth of $182 \mathrm{~m}$. We suppose that the hyperbola corresponds to a tilting tectonic area intersecting Lift I approximately in the middle that has been formed on a prominent intra-layer slip or a nappe structure of the Líšeň formation. A horizontal reflection between the positions of $30 \mathrm{~m}$ and $120 \mathrm{~m}$ at the depth of $180 \mathrm{~m}$ is also present. At the depth of $240-260 \mathrm{~m}$, a number of small reflections are apparent on the radarogram in a continuous strip and are interpreted as reflections from inhomogeneities and material lying on the bottom of Lift I and the ceiling of Lift II.

Other prominent hyperbolas appear on the radarogram at the depths of $305 \mathrm{~m}$ and $320 \mathrm{~m}$ with the peaks in the positions of $180 \mathrm{~m}$ a $150 \mathrm{~m}$, which can be interpreted as local inhomogeneities formed on an intra-layer slip or a nappe inside the Macocha formation, as can be seen from the linear continuation between the positions of 30 a $70 \mathrm{~m}$ at the depth of $325-340 \mathrm{~m}$.

On profiles P10 and P12, we can clearly see a subhorizontal boundary at the depth of $360 \mathrm{~m}$ with the total length of nearly $100 \mathrm{~m}$ (from the $90 \mathrm{~m}$ position on P10 to the $20 \mathrm{~m}$ position on P12 - see Fig. 5). At the beginning of this structure, there is an indication of a hyperbola, suggesting a presence of a linear (2-D) or isometric (3-D) structure that reflects electromagnetic pulses to all directions. Another sub-horizontal boundary is detectable on profile $\mathrm{P} 10$ at the depths of 560-580 m (Fig. 5).

We did not detect any distinctive sub-horizontal boundary in the radarogram of profile P13, which suggests diminishing corrosion in the area more distant from the Hranice Abyss, including occurrence of the most significant tectonic lines. On the other hand it doesn't mean that there are not any boundaries or tectonics below the profile P13. Their thickness could be too small for the visibility on reflected rays.

The interpretation of the detected inhomogeneities (Fig. 5) shows that the whole area north of the Hranice Abyss is intersected by a number of tectonic structures, with both open spaces (e.g. at the beginning of profile P9 on $20-70 \mathrm{~m}$ positions at the depths of $105 \mathrm{~m}$ and $160 \mathrm{~m}$ ), and sub-horizontal boundaries, especially at the depth of 485-500 m. This underground depth corresponds, approximately, to the depth of 420-440 m below water level, where we expect to find the bottom of Lift II which is approx. $15-35 \mathrm{~m}$ lower than the bottom depth as recently detected by means of the robot on the guiding cable (404 m, 27-09-2016) (Guba 2016). Such sub-horizontal space has developed throughout the area north of the Hranice Abyss.

The fact that the open spaces do not end at the depth of $485-500 \mathrm{~m}$ is supported by the reflections on the sub-horizontal boundary that come from the depths of approx. $580 \mathrm{~m}$ below the ground, i.e. approx. $515 \mathrm{~m}$ below the water level. These reflections were detected both north of the abyss at the beginning of profile P2, and, more distinctively, on profile P10 south-east of the abyss (Figs. 2 and 4).

The interpretation of individual geophysical boundaries in this area is quite a difficult task. Complicated tectonic development is behind the stratigraphic inversion in the drilling hole of Opatovice-1 (Dvořák et al. 1981). The karstification is developed in Devonian-Carboniferous (Givetian to Tournaisian) carbonates of the Macocha and Líšeň Formation (Dvořák, Friáková 1978).

A part of the carbonate sequence was overprinted by late Variscan penetrative, which largely controls karst morphology. The thickness of the carbonate succession is not known in the Hranice Karst. The Palaeozoic rocks are deformed into a thin-skinned stack of thrust sheets separated by N/NW-dipping thrust faults (Čížek, Tomek 1991).

Theoretically, the issue of the depth of the Hranice Abyss could be resolved by the knowledge of the total 
thickness of carbonates. Basement igneous rocks, however, were not detected in the Hranice Karst by any drilling. The nearest drilling at Choryně-9 (Vysoká) provided evidence of igneous rocks at the depth of $1462 \mathrm{~m}$, while no such rocks were encountered by the drilling at Valašské Meziříčí (maximal depth of $3036 \mathrm{~m}$ ) and at Potštát-1 (maximal depth of $4200 \mathrm{~m}$ ). Part of the hydrothermal fluids found in the Hranice Abyss belongs to the outer mantle of the Earth (Meyberg, Rinne 1995). This indicates the necessary presence of an exit route that goes through the basement igneous rocks. Therefore, the existence of the Hranice Abyss cannot be connected with Palaeozoic carbonates only; its continuation is probably to be found in the basement rocks.

\section{Results of measurement in the quarry of Malá Dohoda}

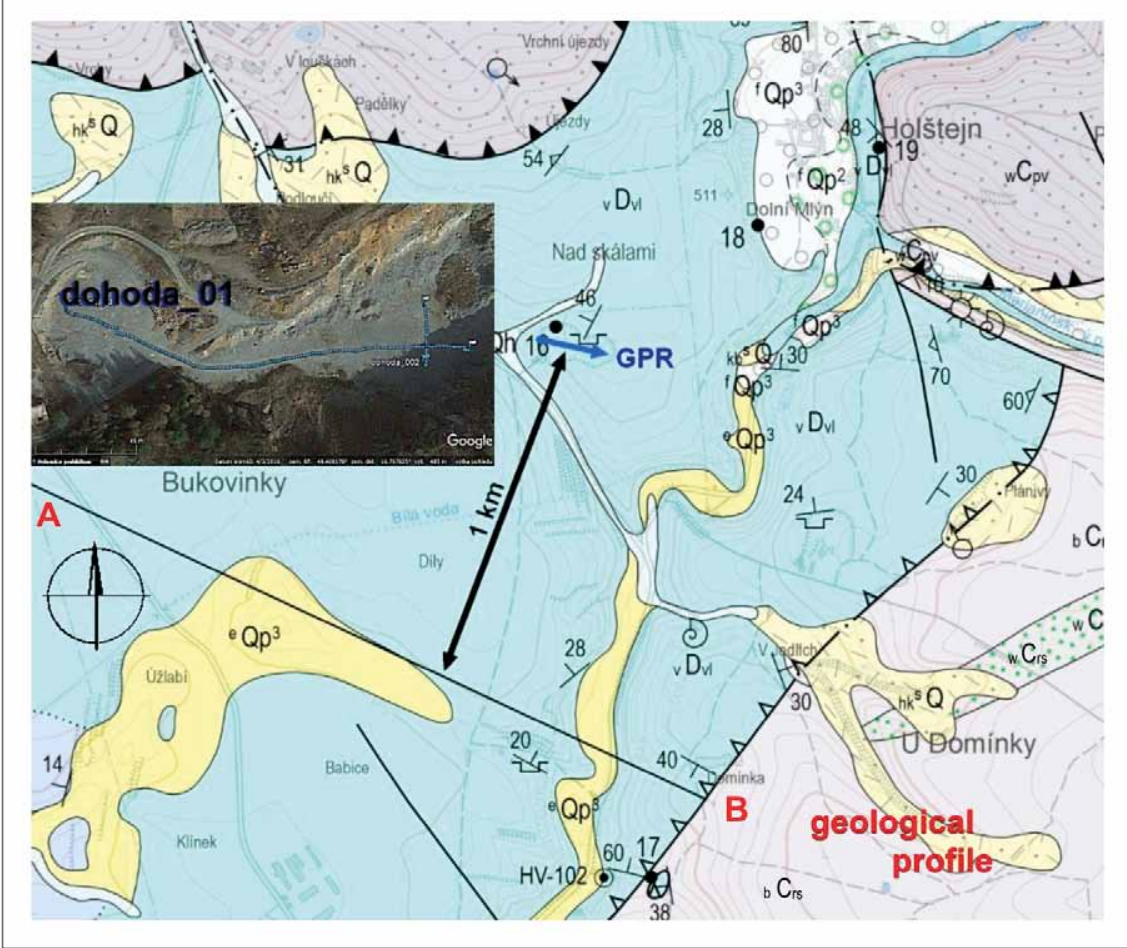

Fig. 6: Profiles Dohoda_001 and Dohoda_002 in the quarry of Malá Dohoda, Holštejn, approximately $1 \mathrm{~km}$ from the geological cross-section (Baldík et al. 2017). Profile names are indicated at the beginning of each profile. Explanations: ${ }^{e} \mathrm{Qp}^{3}-$ loess clay, ${ }_{\mathrm{w}} \mathrm{C}_{\mathrm{pv}}-$ massive greywackes (Ponikev Fm.), ${ }_{w} \mathrm{C}_{\mathrm{rs}}-$ massive greywackes (Rozstání Fm.), ${ }_{\mathrm{b}} \mathrm{C}_{\mathrm{rs}}-$ shales (Rozstání Fm.) ${ }_{\mathrm{v}} \mathrm{D}_{\mathrm{vl}}-$ Vilémovice limestone, ${ }_{\mathrm{v}} \mathrm{D}_{1}-$ Lažánky limestone, ${ }_{\mathrm{v}} \mathrm{D}_{\mathrm{va}}-$ Vavřinec limestone.

In order to carry out an

independent test of the penetration depth of the Roteg limestone quarry, the municipality of Holštejn $\left(16.767978^{\circ}\right.$, GPR at a different location as well as to connect the radaro- $49.400041^{\circ}, 487.8 \mathrm{~m}$ ) (Fig. 6), on 14 May 2017. Around the gram to the nearby geological drills which were absent in quarry, there is a new geological cross-section constructed Hranice, we measured the bottom of the Malá Dohoda

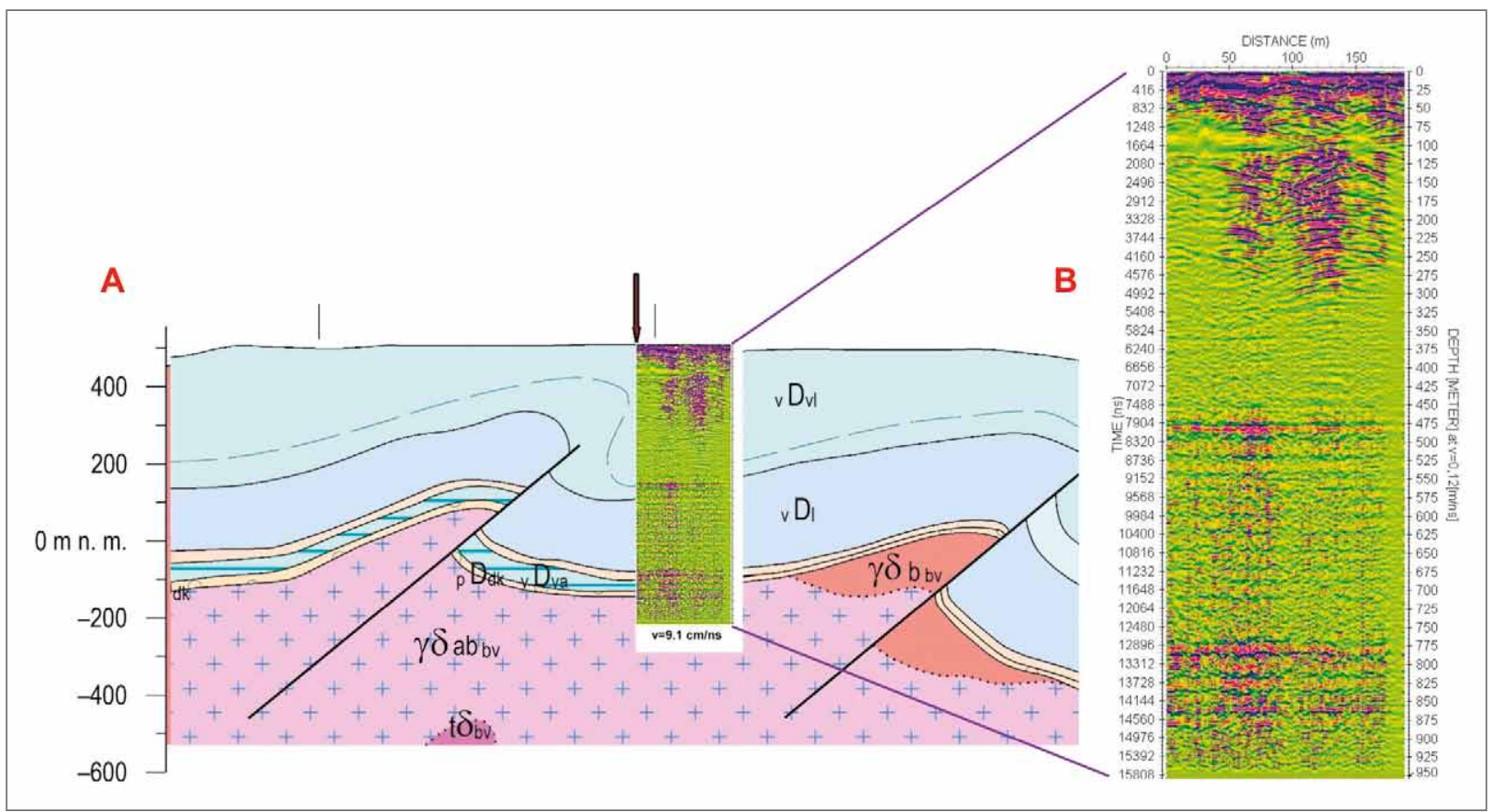

Fig. 7: The geological cross-section at the quarry of Malá Dohoda (Baldík et al. 2017) and the radarogram on the profile of Dohoda_001. The red arrow marks the location of the quarry of Malá Dohoda ( $1 \mathrm{~km}$ off the profile). Explanations: $\mathrm{D}_{\mathrm{vl}}-\mathrm{Vile}_{\mathrm{m} o v i c e}$ limestone, ${ }_{v} D_{1}-$ Lažánky limestone, ${ }_{v} D_{v a}-$ Vavřinec limestone, ${ }_{p} D_{d k}-$ Devonian clastics, $\gamma \delta b_{b v}$ - biotite granodiorite to granite, $\gamma \delta a b_{b v}-$ amphibole-biotite to biotite-amhpibole granodiorite. 
on the basis of the HV-101 and HV-102 deep boreholes and the surface geological mapping (Baldík et al. 2017).

We plotted the radarogram of the longest profile (Dohoda_001) of the length of $188 \mathrm{~m}$ onto the crosssection of the geological profile to compare the depths of reflexive boundaries and changes in lithology (Fig. 7).

The optimum correlation of the boundary depths between the Vilémovice and Lažánky limestones at the depth of $400 \mathrm{~m}$ and significant reflections would be $10 \mathrm{~cm} / \mathrm{ns}$ for the wave speed. The optimum correlation of the whole limestone sequence and significant reflections is for the wave speed of $9.1 \mathrm{~cm} / \mathrm{ns}$ (Fig. 7), but the real thickness of the limestone sequence is probably bigger under the quarry than indicated by the cross-section due to the inclination of the strata towards the $\mathrm{N}-\mathrm{E}$, i.e., toward the quarry. For the table wave speeds of $12 \mathrm{~cm} / \mathrm{ns}$ in limestone, all the boundary depths between the Lažánky limestone and basement clastics - as well as basement of Devon sitting on the granodiorites of the Brno massif - move to about $20 \%$ bigger depths. The character of reflections, however, definitely corresponds to the lithology of all the rocks. In the Vilémovice limestone that is very clean and compact, a number of "point" reflections are observed, probably coming from cavities or caves up to the depth of approx. $250 \mathrm{~m}$. The layered structure is visible in the Lažánky limestone. In the case of the basal Devonian clastics, it is even more evident. The relative thickness of all the formations corresponds to the geological cross-section as well. The discrepancy of approx. $20 \%$ between the depths in the geological cross-section and the depths detected from the GPR for the wave speed in limestone $(12 \mathrm{~cm} / \mathrm{ns})$ can be caused by both the lower wave speeds in limestone in the given location and inaccuracies in determining all the boundaries in the geological cross-section. In fact, the cross-section was only based on the data from the nearby boreholes, the tilting layers in the boreholes, and on the surface, which does not have to be identical at bigger depths. Moreover, the distance between the geological cross-section and the quarry of Malá Dohoda is approx. $1 \mathrm{~km}$, and against the general gradient of the layers.

The verified maximal penetration depth of almost $800 \mathrm{~m}$ in optimal conditions in the Malá Dohoda quarry using $25 \mathrm{MHz}$ antennas and $20 \mathrm{kV}$ pulses corresponds to the depth of $98 \mathrm{~m}$ using common GPR with $25 \mathrm{MHz}$ antennas and short pulses of length less or equal to 3 ns, because conventional GPRs have power output of approximately $300 \mathrm{~W}$. Because these GPRs use CMOS off-switches, the output signal on antenna is rather sinusoidal and not pulse; the real maximal penetration depth is approximately twice less than for pulses, which corresponds to the experimentally estimated (Smith and Jol 1995) or theoretically derived maximal penetration depth (Chamberlain et al. 2000). If we would use the pulses of the power of TW like during a lightning, the maximal penetration depth would be at least $100 \mathrm{~km}$, i.e. the whole Earth's crust.

\section{Conclusion}

Conventional GPRs are able to detect reflections of inhomogeneity from the depths of about 20-30 m below the surface under optimal conditions (karst area without a thick soil cover).The new kind of GPR Roteg ver. 2.0 with extremely high power output (up to $20 \mathrm{MW}$ in the pulse regime) was used for testing the "maximal penetration depth" parameter under optimal conditions in the Hranice Karst near the Hranice Abyss and in the quarry of Malá Dohoda located in the Moravian Karst. Typical hyperbolas from 2-D or 3-D structures (mainly caves) are clearly detectable on filtered radarograms even from the depths of $320 \mathrm{~m}$, i.e., $250 \mathrm{~m}$ below the water level in the Hranice Abyss - something which was not expected. Sub-horizontal reflections are detectable on radarograms from the depths of up to $580 \mathrm{~m}$; this was limited by the length of the record in this case.

The measurement in the quarry of Malá Dohoda located in the Moravian Karst confirmed the results from the Hranice Abyss. Typical hyperbolas were seen on radarograms to the depths of $250 \mathrm{~m}$, which showed the karstification of limestone to these depths. Moreover, all significant changes of lithology were detectable on the filtered radarogram to the maximal depths of approx. $850 \mathrm{~m}$ for the wave speed of $12 \mathrm{~cm} / \mathrm{ns}$ (or $650 \mathrm{~m}$ for $9.1 \mathrm{~cm} / \mathrm{ns}$ ). We can also validate that, under the optimum conditions of karst without the soil cover, the penetration depth of the new type of the Roteg GPR - particularly its new version 2.0 with the longest antennas $(6 \mathrm{~m})$, the low frequency $(25 \mathrm{MHz})$, and the maximum voltage on the antennas $(20 \mathrm{kV})$ - is at least $700 \mathrm{~m}$.

\section{Acknowledgements}

We express our gratitude to both of the anonymous reviewers for their comments and improvements of the text. The research was possible thanks to the institutional support of Mendel University in Brno. 


\section{References}

Annan, A. P. (2005). Ground-penetrating radar. - In: Butler, D. K. (ed.): Near surface geophysics, Investigations in Geophysics 13, 357-438, Society of exploration geophysicists, Tulsa.

Baldík, V., Buriánek, D., Novotný, R., Otava, J., Rez, J., Sedláček, J., Vít, J. (2017). Basic geological map of the Czech Republic $1: 25$ 000, sheet 24-233 Ostrov u Macochy. - MS, ČGS Brno.

Čížek, P., Tomek, C. (1991). Large-Scale thin-skinned tectonics in the eastern boundary of the Bohemian Massif. - Tectonics, $10,273-286$.

Chamberlain, A. T., Sellers, W., Proctor, C., Coard, R. (2000). Cave detection in limestone using ground penetrating radar. Journal of Archaeological Science, 27, 957-964. https://doi.org/10.1006/jasc.1999.0525

Dvořák, J., Friáková, O. (1978). Stratigraphy of the Palaeozoic near Hranice na Morave. - Czech Geological Survey report, 18, 1-50.

Dvořák, J., Friáková, O., Galle, A., Kalvoda, J., Maštera, L., Otava, J., Přichystal, A., Skoček, V. (1981). Paleozoikum ve vrtu Opatovice 1 na Hranicku (SV Morava). - Časopis Slezského Muzea (Opava), Řada A, 30, 211-229, Opava.

Dvořák, J., Štelcl, O., Demek J., Musil R. (1993). Geologie a geomorfologie Moravského krasu. - In: Musil R. et al.: Moravský kras - Labyrinty poznání, 32-76, GEOprogram, Adamov.

Geršl, M., Kalenda, P., Havlín, A., Duras, R. (2007). Geophysical mapping by very low frequencies method and drilling survey in the vicinity of the Hranická Chasm (Hranice Karst) - Geological Research in Moravia and Silesia in the year 2006, 92-94 (in Czech).

Gosar, A. (2012). Analysis of the capabilities of low frequency ground penetrating radar for cavities detection in rough terrain conditions: The case of Divača cave, Slovenia. - Acta Carsologica, 41, 1, 77-88. https://doi.org/10.3986/ac.v41i1.49

Gosar, A., Čeru, T. (2016). Search for an artificially buried karst cave entrance using ground penetrating radar: a successful case of locating the S-19 Cave in the Mt. Kanin massif (NW Slovenia). - International Journal of Speleology, 45, 2, 135-147. http://dx.doi.org/10.5038/1827-806X.45.2.1979

Guba, M. (2016). Tisková zpráva k hloubkovému průzkumu Hranické propasti a dosažení nové maximální hloubky $-404 \mathrm{~m}$. http://www.hranickapropast.cz/.

Hašek, V., Štelcl, O. (1973). Některé výsledky geofyzikálního výzkumu Moravského krasu. - Československý kras, 24, 37-49.

IRIS GPRs (2019). Ground penetrating radars by Mastrad Limited, Douglas, United Kingdom. http://www.mastrad.com/gpr.htm.

Kalenda, P., Geršl, M., Havlín, A., Duras, R. (2007). Geofyzikální mapování metodou velmi dlouhých vln v okolí Hranické propasti - první výsledky. - Speleofórum 2007, 82-83.

Kalenda, P., Tengler, R., Šebela, S., Blatnik, M., Gosar, A. (2018). Detection of Divaška jama behind Trhlovca jama. - Acta Carsologica, Vol. 47, No. 2-3, 153-167. http://dx.doi.org/10.3986/ac.v47i2-3.5187

Kamenský, S. (2016). Hranická propast je nejhlubší na světě, robot se ponořil do 404 metrů. Idnes.cz, 2016-09-30, Available online: http://olomouc.idnes.cz/hranicka-propast-nejhlubsi-sladkovodni-jeskyne-na-svete-hloubka-404-metru-1qz-/ olomouc-zpravy.aspx?c=A160930_092036_olomouc-zpravy_stk. 30. 9. 2016.

Łyskowski, M., Mazurek, E., Zientek, J. (2014). Ground Penetrating Radar investigation of limestone karst at the Odstrzelona Cave in Kowala, Swietokrzyskie Mountains, Poland. - Journal of Cave and Karst Studies, 76, 3, 184-190. http://dx.doi. org/10.4311/2014EX0001

Meyberg, M., Rinne, B. (1995). Messung des 3He/4He-Isotopen-verhältnisses in Hranicka Propast (Tschechische Republik), Die Höhle. - Z. Karst und Höhlenkunde 46, 1, 5-8.

Musil, J. (2017). The Hranice Abyss became the deepest underwater abyss in the world! - In: Bosák, P., Geršl, M., Novotná, J. (ed.): Speleofórum, 36, Proceedings from Meeting of cavers in the Moravian Karst, 10-15, Czech Speleological Society, Sloup, Czech Republic.

RTG-Tengler (2013). Available from: http://georadar.rtg-tengler.cz/geologicky-zlom-u-sobotky, 20. 10. 2020.

Slezák, L. (1955-1956). Geologický výzkum devonských vápenců v okolí Mokré. - Diplomová práce, 1-76. Universita Jana Evangelisty Purkyně. Brno.

Slezák, L., Štelcl, O. (1963). Geologické poměry jižní části Moravského krasu a přilehlých území. - Časopis Moravského muzea, $48,89-104$.

Smith, D. G., Jol, H. M. (1995). Ground penetrating radar: antenna frequencies and maximum probable depths of penetration in Quaternary sediments. - Journal of Applied Geophysics, 33, 1-3, 93-100. http://dx.doi.org/10.1016/0926-9851(95)90032-2

Starnawski, K. (2012). Hranická propast: 217 m. https://vimeo.com/44709652. 20. 10. 2020.

Šteffan, M., Melichar, R. (1996). Tzv. plástevnaté vápence a tektonika Hranického krasu. - Seminář Skupiny tektonických studií. Program, abstrakta, exkurzní průvodce, 48 s., Jeseník.

Šráček, O., Geršl, M., Faimon, J., Bábek O. (2019). The geochemistry and origin of fluids in the carbonate structure of the Hranice Karst with the world's deepest flooded cave of the Hranicka Abyss, Czech Republic. - Applied Geochemistry, 100, $203-212$. https://doi.org/10.1016/j.apgeochem.2018.11.013

Tengler, R., Kalenda, P., Doležal, F. K., Chlup, L. (2016). Testování nového typu georadaru s velkým hloubkovým dosahem. Speleofórum, 35, 35-42.

van der Kruk, J., Slob, E. C., Fokkema, J. T. (1999). Background of ground-penetrating radar measurements. - Geologie en Mijnbouw, 77, 177-188. https://doi.org/10.1023/A:1003546619639

Vysoká, H. (2017). Hydrogeologický výzkum Hranické propasti v rámci projektu Expedice Neuron - předběžné výsledky. - Speleofórum, 36, 16-21. 